The thirteenth-century visitation records of Hereford diocese

Ian Forrest

Oriel College, Oxford, OX1 4EW (ian.forrest@history.ox.ac.uk)

Christopher Whittick

East Sussex Record Office, The Keep, Woollards Way, Brighton, BN1 9BP 


\section{The thirteenth-century visitation records of Hereford diocese ${ }^{*}$}

\section{Abstract}

When visitation of the laity became a regular feature of parish and diocesan life towards the end of the thirteenth century it relied upon new forms of documentation. Three visitation records from late- thirteenth century Hereford diocese are edited here, and the character of the documents produced under the pioneering bishops Thomas Cantilupe and Richard Swinfield, is described and analysed. The authors discuss the reasons for the emergence of regular episcopal visitation around this time, and the nature and utility of the documents which it produced and on which its viability depended.

\section{Article text}

In late-thirteenth century England the visitation of parishes was becoming an intrusive, profitable and effective organ of diocesan government, as well as a prominent political issue. ${ }^{1}$ The period between 1100 and 1250 had seen the emergence of parishes as the main form of local ecclesiastical organization; a growth in the power of bishops, who had become the managers of relationships between the parish clergy and patrons of churches; the development of literate bureaucracies in episcopal chanceries; and an

\footnotetext{
* The authors would like to thank Rosalind Caird of Hereford Cathedral Library and Archives for her unstinting assistance and encouragement over many years; Michael Athanson, Deputy Map Librarian and Geospatial Data Specialist in the Bodleian Library, who assisted in the preparation of the map; and the two anonymous readers for the journal, whose comments improved the text of the edited documents and encouraged us to set them in a broader context.

${ }^{1}$ C.R. Cheney, Episcopal Visitation of Monasteries in the Thirteenth Century (Manchester, 1931); D.L. Douie, Archbishop Pecham (Oxford, 1952), pp. 192-234; R.C. Finucane, 'The Cantilupe-Pecham Controversy', in M. Jancy, ed., St Thomas Cantilupe Bishop of Hereford. Essays in his Honour (Hereford, 1982), pp. 120-1.
} 
increasing concern with pastoral care. ${ }^{2}$ However, before the mid-thirteenth century it does not appear that bishops had been able to gain much traction on local society. This was remedied by the formation of an alliance with the local leaders of lay society, the upper stratum of the peasantry, who were as interested in regulating the social and moral lives of their neighbours as they were in holding the parish clergy to the standards that they had been taught, by synodal legislation and other means, to expect of them. Although monasteries had been subjected to episcopal visitation in the early- to midthirteenth century, it was only around 1270 that the journeys of bishops through their dioceses became the vehicle for the proactive investigation of lay and clerical faults. ${ }^{3}$ The causes, timing and mechanisms of this change across the dioceses of thirteenthcentury England have been discussed in detail in a recent article by lan Forrest. ${ }^{4}$ Here, we seek to add depth to one particular aspect of this 'transformation' - the reliance of visitation upon the production and preservation of written records - by exploring the evidence from a single diocese (Hereford) which appears to have been at the forefront of developments, and by publishing editions of three early visitation records.

\footnotetext{
2 J. Blair and R. Sharpe, eds., Pastoral Care Before the Parish (Leicester, 1992); J. Blair, The Church in Anglo-Saxon Society (Oxford, 2005), pp. 368-504; M. Burger, Bishops, Clerks, and Diocesan Governance in Thirteenth-Century England (Cambridge, 2012); S. Hamilton, Church and People in the Medieval West, 900-1200 (Harlow, 2013); K. Harvey, Episcopal Appointments in England c.1214-1344: from Episcopal Election to Papal Provision (Farnham, 2014); P. Hoskin, 'Robert Grosseteste and the Simple Benefice: a Novel Solution to the Complexities of Lay Presentation', Journal of Medieval History, 40 (2014), pp. 24-43; id., 'Authors of Bureaucracy: Developing and Creating Administrative Systems in English Episcopal Chanceries in the Second Half of the Thirteenth Century', in P. Binski and E.A. New, eds., Patrons and Professionals in the Middle Ages: Proceedings of the 2010 Harlaxton Symposium (Donington, 2012), pp. 61-78.

${ }^{3}$ Cheney, Episcopal Visitation of Monasteries.

${ }^{4}$ I. Forrest, 'The Transformation of Visitation in Thirteenth-Century England', Past and Present, (2013), pp. 3-38.
} 
Although Hereford was among the poorest of the English dioceses it was blessed (or cursed) with a series of able and energetic bishops who showed how the ideals of pastoral reform might be translated into administrative practice. This would not be our picture of Hereford were we forced to rely upon surviving collections of reforming synodal constitutions, for which the evidence is sparse. ${ }^{5}$ However, a full evaluation of the evidence for visitation during the episcopates of Thomas Cantilupe (1275-1282) and Richard Swinfield (1283-1317) suggests a very active interest in pastoral care. These two bishops were vigorous in the conduct of visitation and pioneering in the creation and preservation of visitation records. These records, including those discussed and edited here, were of two main types. ${ }^{6}$ The first might be described as the itinerary: it was important to keep a record of the places visited and the fees (discussed in more detail below) that were collected. Such itineraries provided both a form of rudimentary accounting and a means to establish evidence of jurisdiction. ${ }^{7}$ The second is that which we usually think of as a visitation record: the reports of local panels concerning the faults and offences of their parish, and the visitor's responses which constituted a process of pastoral, and sometimes judicial, correction. The texts edited here consist of one itinerary and two partial records of reported faults among the clergy and laity of the diocese.

\footnotetext{
${ }^{5}$ Constitutions attributed tentatively to Bishop Hugh Foliot (1219-1234) in F.M. Powicke and C.R. Cheney, eds., Councils and Synods with Other Documents Relating to the English Church, II: A.D. 1205-1313 (Oxford, 1964), pp. 182-98.

${ }^{6}$ The importance of differentiating practice in different dioceses is emphasised by N. Coulet, Les Visites Pastorales, Typologie des Sources du Moyen Âge Occidental, 23 (Turnhout, 1977), p. 29.

7 J. Sabapathy, Officers and Accountability in Medieval England 1170-1300 (Oxford, 2014); I. Forrest, 'The Survival of Medieval Visitation Records', Archives, 37 (2012), pp. 1-10.
} 
We firmly believe that visitation records offer historians an unrivalled means of studying the interactions between episcopacy, clergy and laity and the ways in which they shaped social and religious life. This has been amply demonstrated by the most recent work on medieval visitations, which has shifted away from uncritical attempts to gauge the spiritual health of a diocese, focussing instead on the capacity of the records to reveal the active pursuit of social and moral goals relating to lay and clerical behaviour, neighbourliness, sexual activity and the provision of pastoral care. ${ }^{8}$ There is a great deal more that could be done in this field, although it is not our primary purpose to pursue that here. Our focus is on the records themselves and the administrative practices they disclose.

Indeed it is impossible to discuss the conduct of visitation without a thorough understanding of the documentation it generated, for it relied in very large measure upon such written records. Moreover it also depended upon the effective preservation of those records for the duration of their administrative usefulness. While the practice of most dioceses seems to have been to destroy visitation records once the cases they dealt with had been 'closed', at Hereford such archival sifting and purging seems to have taken place a long time after the documents were first written. ${ }^{9}$ This fact permits us to begin not in the late-thirteenth century with the documents edited below, but in the mid-fourteenth century in the company of two diocesan administrators as they

\footnotetext{
8 J.D. Thibodeaux, 'The Sexual Lives of Medieval Norman Clerics', in A. Classen, ed., Sexuality in the Middle Ages and the Early Modern Times: New Approaches to a Fundamental Cultural-Historical and LiteraryAnthropological Theme (Berlin, 2008), pp. 471-83; J. Werner, 'Promiscuous Priests and Vicarage Children', in J.D. Thibodeaux, ed., Negotiating Clerical Identities: Priests, Monks and Masculinities in the Middle Ages (Basingstoke, 2010), pp. 159-81; M. Kelleher, The Measure of Woman: Law and Female Identity in the Crown of Aragon (Philadelphia ,2010); Forrest, 'Transformation of Visitation'.

${ }^{9}$ Forrest, 'Survival of Medieval Visitation Records'.
} 
searched the Hereford capitular archives for historical evidence that would help their master - the bishop - to answer a challenge to his jurisdiction. The fact that they were able to do this attests to the Hereford practice of preserving visitation records, and what they found is enormously useful to a reconstruction of the practice of visitation of the laity in its earliest phase.

Bishop John Trillek (1344-1361) was looking for evidence to support his jurisdictional claims against those of Bromfield and Monmouth Priories. These were local disputes with long histories. ${ }^{10}$ Both houses had challenged Trillek's right to visit them but also, crucially, his right to receive 'procurations'. These were the fees paid to the visitor by the place visited, usually in kind (food, drink and lodging), but sometimes in money, and it was only through the efficient management of this system of payments that visitation was a viable operation, since all diocesan activities had to be largely selffunding. ${ }^{11}$ In 1353 Bishop Trillek came to an agreement with Gloucester Abbey (the mother house of Bromfield) establishing the bishop's right to visit the priory and receive

\footnotetext{
${ }^{10}$ Bishops John le Breton and Thomas Cantilupe had difficulty securing procurations from Gloucester in respect of Churcham and Much Cowarne, which were appropriated to the abbey's daughter-house at Bromfield: J. Barrow, ed., English Episcopal Acta, 35: Hereford 1234-1275 (Oxford, 2009), no. 134; The Register of Thomas de Cantilupe, Bishop of Hereford (A.D. 1275-1282), ed. R.G. Griffiths and W.W. Capes (Canterbury and York Society, 2; London, 1906-7), pp. 237-9, 240, 256-8. Bishop Swinfield was also active in defending his right to visit appropriated churches. He threatened deprivation of benefice against the rector of Winstanstow in 1288 in respect of unpaid procurations, and was in dispute with Worcester cathedral priory over Lindridge parish in 1310: Registrum Ricardi de Swinfield, Episcopi Herefordensis, A.D. MCCLXXXIII-MCCCXVII, ed. W.W. Capes (Canterbury and York Society, 6; London, 1909), pp. 161-2, 455-7.

${ }^{11}$ Cheney, Episcopal Visitation of Monasteries, pp. 104-118. R.N. Swanson, 'Episcopal Income from Spiritualities in Later Medieval England: the Evidence for the Diocese of Coventry and Lichfield', Midland History, 13 (1988), pp. 1-20. During Cantilupe's episcopate and the first half of Swinfield's (to 1298), the 1246 canon of Innocent IV that procurations should only be received in kind, was in force, but in 1298 Boniface VIII allowed the receipt of money once again: VI 3.20.1 (Romana ecclesia), VI 3.20.3 (Felicis recordationis) in Corpus iuris canonici, ed. Emil Richter and Emil Friedberg (2 vols., Leipzig, 1879-81; repr. Union, NJ, 2000), ii. 1056-8.
} 
procurations of 40 shillings or its equivalent in victuals once every three years. ${ }^{12}$ But this settlement was reached only after canon Thomas Talbot had searched the cathedral registry and found evidence in the bishop's favour. Bromfield's claim to exemption from episcopal oversight had been based upon charters of Edward the Confessor, Henry II, and Bishop Gilbert Foliot (1139-1163). But though these august muniments had been copied into Bishop Swinfield's main episcopal register Bishop Trillek believed that the newly-discovered evidence of practice and precedent was superior. ${ }^{13}$ In 1354 a similar situation arose in relation to Monmouth Priory. Bishop Trillek commissioned canon John Boter to comb the archives to find documentation of Monmouth's payment of procurations, for the convent itself and on behalf of the parish church. These proofs would, it was hoped, establish the bishop's rights of visitation and procuration once and for all. ${ }^{14}$ Canons Talbot and Boter compiled their findings into two lists of visitation records supporting the bishop's claim to jurisdiction. That they were able to do this reveals a degree of systematic archival management extending from the 1270 s into the middle of the following century. Moreover the lists are enormously informative about the documentation and practice of visitation in its earliest period, and it is worth describing them in some detail. We will refer to the documents in the lists using the

\footnotetext{
${ }^{12}$ Registrum Johannis de Trillek, Episcopi Herefordensis, A.D. MCCCXLIV-MCCCLXI, ed. J.H. Parry (Canterbury and York Society, 8; London, 1912), pp. 238-40. On the status of Bromfield priory see D. Knowles and R.N. Hadcock, Medieval Religious Houses: England and Wales (London, 1971), pp. 52, 61; M. Heale, The Dependent Priories of Medieval English Monasteries (Woodbridge, 2004), p. xvi.

${ }^{13}$ Reg. Swinfield, pp. 425-6. For a discussion of the early charters of Bromfield Priory, see J. Blair, 'Secular Minster Churches in Domesday Book', in P.H. Sawyer, Domesday Book: a Reassessment (London, 1985), pp. 128-31.

${ }^{14}$ Monmouth Priory was a daughter house of the Benedictine abbey of St Florent in Saumur: Knowles and Hadcock, Medieval Religious Houses, p. 71.
} 
shorthand 'TALBOT' and 'BOTER' followed by a number assigned to each item: i.e. TALBOT 1-7 and BOTER 1-6.

Canon Talbot identified seven documents relevant to the Bromfield dispute. ${ }^{15}$ TALBOT 1 was a 'register of the blessed Thomas of Cantilupe' containing reports from a visitation of Bromfield in which three or four monks had been accused of trying to deceive the bishop in advance of the visitation, two more of being archers and hunters, while together the monks were said to do 'no good with the revenues of the chapel of Ashford Bowdler; they sell them every year to lay merchants from Ludlow'. TALBOT 2 was 'a certain letter from the said bishop to the precentor of Hereford, then his vicar general, found in the register of the said bishop'. In it Cantilupe thanked the precentor for his efforts but told him that it was still not clear what procurations he was owed, unless from the visitation and reconciliation of Much Cowarne (Cantilupe said he had visited the church and priory of Bromfield once). TALBOT 3 was a document in the same register' recording that on Friday after the feast of St Chad 1275 (8 March), Cantilupe visited the priory of Bromfield and was paid (procuratus) in victuals. TALBOT 4 was possibly in the same register again, recording a repetition of the 1275 visitation on 7 March 1280. TALBOT 5 was a document 'in the register of Richard [Swinfield] the next bishop' recording the visitation on 2 February 1278 (sic) $^{16}$ of Bromfield priory, where Swinfield received procurations in victuals, and of the parish church where he also received procurations. ТАLВOT 6 was another document 'in the same register' for 1286

\footnotetext{
${ }^{15}$ Reg. Trillek, pp. 236-8.

16 There is a discrepancy in the dates here. 1278 is said to be 'the first year from his consecration' but Swinfield was consecrated in 1283 . It could be a document pertaining to Cantilupe, recorded in Swinfield's register, but he was consecrated in 1275 .
} 
when Swinfield visited the parish and the priory on 6 and 7 February. Finally, TALBOT 7 was an entry 'in the same register' recording that on 3 May 1298 Swinfield visited the monks of Bromfield and received procurations in victuals.

Canon Boter's search clearly went through some of the same material. BOTER 1 was a 'register' of Bishop Cantilupe entitled 'Roll of visitations from the time of Bishop Thomas of favoured memory', which contained entries relating to Monmouth Priory in 1275 and, under the title 'the fifth year', entries relating to the priory and the parish church in $1280 .{ }^{17}$ BOTER 2 was a 'roll or register' of Bishop Swinfield for 1284 entitled 'First year, names of the churches in Hereford diocese which the venerable father lord Richard visited', recording the visitation of Monmouth parish church. ${ }^{18}$ BOTER 3 was a 'roll or register' of Bishop Swinfield entitled 'Fourth year and second circuit of visitation' containing a reference to the visitation of Monmouth Priory and parish in $1286 .{ }^{19}$ BOTER 4 was a 'roll or register' of Bishop Swinfield entitled 'Roll of the fourth visitation of the lord [bishop] of his diocese' recording a visitation of both parish and priory in $1292 .^{20}$ BOTER 5 was a 'roll or register' of Bishop Swinfield entitled 'The sixth circuit of the lord's visitations' recording a visitation of both parish and priory in $1300 .^{21}$ BOTER 6 was a roll from the time of bishop Swinfield entitled 'Roll of household arrears from outstanding

\footnotetext{
${ }^{17}$ Reg. Trillek, p. 222: 'Rotulus visitationum de tempore bone memorie episcopi Thome.' The annotation clearly post-dates Cantilupe's episcopacy.

${ }^{18}$ Reg. Trillek, p. 222: 'annus primus, Nomina ecclesiarum Herefordensis diocesis quas venerabilis pater, dominus Ricardus visitavit.' The phrase 'roll or register' indicates that 'registrum' could refer not only to bound books, but also more generically to muniments of all sorts: see M.T. Clanchy, From Memory to Written Record: England 1066-1307 (3rd edn. Oxford, 2013), pp. 105-6.

${ }^{19}$ Reg. Trillek, p. 222: 'Annus quartus et secundus circuitus in visitando.'

${ }^{20}$ Reg. Trillek, p. 222: 'Rotulus quartus visitationum domini per diocesim suam.' Given the practice of beginning each the year of grace at the Annunciation on 25 March, it is reasonable to correct this to 1293, which makes it likely that BOTER 4 is HCA 1076, edited below.

${ }^{21}$ Reg. Trillek, p. 222: 'Sextus circuitus in visitationibus domini.'
} 
procurations', in which the priory is said to have owed nothing on its own behalf, but twenty-four marks for six visitations of the parish church. ${ }^{22}$ Most items mentioned in these lists are no longer extant, but two of the texts edited below will be identified in due course as documents handled by Talbot and Boter.

It is important to note that the two canons were clearly searching through records other than the general episcopal registers. TALBOT 1 is a detailed account of the offences discovered during a visitation of Bromfield Priory, and it purports to come from a register of Bishop Cantilupe; but there are no visitation proceedings relating to Bromfield in Cantilupe's general register as it survives today. ${ }^{23}$ TALBOT 3 and 4 also suggest that Cantilupe was keeping discrete records of his visitations, but not necessarily just of one kind: these documents are terse reports of the place visited, the date, and the receipt of procurations, whereas TALBOT 1 was a detailed report of a visitation hearing. TALBOT 2 also purports to come from a register of Bishop Cantilupe, but again it is not in the surviving register. Such a letter from the bishop to the precentor would be a more likely candidate for inclusion in the general register, but Canon Talbot claimed it was in the same register as TALBOT 3. There is no surviving example of such a heterogeneous visitation book anywhere in English episcopal archives

\footnotetext{
${ }^{22}$ Reg. Trillek, p. 222: 'Rotulus domesticorum arreragiorum procurationum secundo factorum.'

${ }^{23}$ Reg. Cantilupe contains visitation injunctions for several other religious houses: Leominster priory for 1276 (pp. 46-9, 79-80, 88-9, 95); Wormsley Priory for 1277 (pp. 144-5); Chirbury Priory for 1277 (pp. 1479); Limebrook Nunnery for c.1279 (pp. 200-2). There is also a commission for the bishop's official to visit Limebrook, Stoke Edith, Awre, Lydney, Tidenham and Woolaston (p. 219), which are called monastic churches, although apart from Limebrook their status is not clear. There are no complete accounts of offences discovered during visitation, of the type described in Talbot 1, anywhere in Cantilupe's register.
} 
of the thirteenth to fifteenth centuries, though examples do survive from thirteenthcentury Normandy and early-sixteenth century Canterbury. ${ }^{24}$

It seems from TALBOT 5, 6, and 7 that Bishop Swinfield was also keeping separate visitation records, as none of those documents made their way into his general register. While that volume does contain a number of visitation injunctions, there is nothing of the type indicated by the documents in the list. ${ }^{25}$ Despite the confusion over dates, it is clear that this separate 'register' was a continuing record of visitations, running from the beginning of Swinfield's episcopate until at least 1298.

This analysis of the two fourteenth-century lists permits us to place the three records edited below into an administrative context. The first, Hereford Cathedral Archives (hereafter HCA) 1050a, is a single parchment membrane measuring $272 \times 326 \mathrm{~mm}$, endorsed 'Visitations of the churches of Hereford diocese made by Lord Richard the bishop of Hereford.' From the name of the bishop (who can only be Swinfield) and a reference to the feast of St Andrew falling on a Thursday, the proceedings can be dated 27 to 30 November 1284, but the document itself seems to have been written years later; palaeographically it cannot be as early as the 1280 s, and a date c.1335 during the

\footnotetext{
${ }^{24}$ The Register of Eudes of Rouen, ed. S.M. Brown and J.F. O'Sullivan (New York, 1964) is one such visitation journal made between 1248 and 1269 recording this Norman archbishop's pastoral activity, combining all the classes of record noted here for Hereford. Cf. Cheney, Episcopal Visitation, pp. 6-11; for recent work on Rigaud's visitations see L. Hicks, 'Exclusion as Exile: Spiritual Punishment and Physical Illness in Normandy, 1050-1300', in E. van Houts, ed., Exile in the Middle Ages: Selected Proceedings from the International Medieval Congress, University of Leeds, 8-11 July 2002 (Turnhout, 2004), pp. 145-58, and A.J. Davis, The Holy Bureaucrat: Eudes Rigaud and Religious Reform in Thirteenth-Century Normandy (Ithaca, 2006). A possible later English candidate is Canterbury Cathedral Archives, DCc/Register/R, a chaper act book containing two distinct sections on sede vacante visitations of Ely and Winchester dioceses in 1500-01, including mandates and letters as well as detecta.

${ }^{25}$ As with Cantilupe's register, records of the visitation of religious houses in Swinfield's register concentrate on Leominster, which was visited in 1283 and 1286: Reg. Swinfield, pp. 14-15, 108-10, 131-2.
} 
episcopate of Thomas Charlton seems more reasonable. Moreover the text is not arranged in the episodic form that we would associate with working visitation records, where the initial reports from the parishes have usually been entered first, and subsequently augmented with procedural notes and further observations, often in a plethora of chaotic interlineations. Instead the initial reports and all follow-up materials are run together in a single neat hand, which strongly suggests a copy made to prove jurisdiction in real or anticipated litigation. ${ }^{26}$ At several points the names of individuals - the bishop conducting the visitation and the prioress of Limebrook - have been replaced by a pair of dots, presumably in an attempt by the copyist to depersonalise the document, though the reason for this is unclear.

The roll contains detailed reports of visitations conducted at the chapels and parish churches of Hope-under-Dinmore, Pudleston, Docklow, Stoke Prior, Eye, Middleton-on-the-Hill, Orleton, Mileshope, Lucton, Eyton, Kimbolton, Brimfield, Croft, Yarpole, Aymestrey, Shobdon, Leinthall, Lingen, and the priory at Limebrook. The hearings were conducted by one 'R. de Hoyton' ${ }^{27}$ special commissioner of the bishop, and the reports comment on a number of matters: the identity of the clergy, whether or not they were resident, dereliction of duty by the bishop's apparitor, non-appearance at visitation, the dependent status of the churches, the destination of tithes paid outside the parish, the state of the church fabric and possessions, whether the cemetery was properly dedicated, and moral offences including adultery, fornication, concubinage,

\footnotetext{
${ }^{26}$ On litigation and the preservation of visitation records see Forrest, 'Survival of Medieval Visitation Records'.

${ }^{27}$ A Master Richard de Hopton was present in the bishop's retinue at the visitation of Leominster priory in April 1283: Reg. Swinfield, p. 15. Given that HCA 1050a is a copy the discrepancy between Hoyton and Hopton is not fatal to such an identification.
} 
incest, usury, domestic violence, prostitution, defamation, and detention of dues and tithes from the church.

Seven of the churches referred to were appropriated to Leominster Priory, and this might indicate that in the second quarter of the fourteenth century Bishop Charlton was paying particular attention to the pastoral care offered by the canons of that house. ${ }^{28}$ Leominster continued to support pastoral care through the provision of vicars in a number of parishes that had been within the administrative parochia of its AngloSaxon minster; it also claimed exemption from episcopal visitation as a daughter house of Reading Abbey. ${ }^{29}$ Both Cantilupe and Swinfield had paid especial attention to Leominster because of these peculiarities, conducting focussed visitations in 1276,1277 , 1283 and 1286. Cantilupe had, in fact, been praised after his death for visiting the priory, a challenge which his predecessors had shunned. ${ }^{30}$ HCA 1050a, even though a 1330s copy of a 1284 visitation, has been excised from a longer roll, suggesting that it may in fact have been the bishop's visitation rights as a whole that were being challenged in the fourteenth century. It might be that this copied roll was broken up at a later date so that the Leominster fragment could be sewn into a place-specific dossier

\footnotetext{
${ }^{28}$ Charlton conducted a major visitation of parishes and religious houses in 1332: Registrum Thome de Charlton, Episcopi Herefordensis, AD MCCCXXVII-MCCCXLIV, ed. W.W. Capes (Canterbury and York Society, 9; London, 1908), pp. 8-10, 20-1, 24, 29-30. For the churches appropriated to Leominster or Reading (Hope-under-Dinmore, Pudleston, Stoke Prior, Eye, Brimfield, and Croft) see J. Barrow, ed., English Episcopal Acta, VII: Hereford 1079-1234 (Oxford, 1993), nos. 11, 137, 268, 310, 352; EEA: Hereford 1234-1275, no. 145.

${ }^{29}$ Brian Kemp, 'Some Aspects of the Parochia of Leominster in the Twelfth Century', in J. Blair, ed., Minsters and Parish Churches: the Local Church in Transition, 950-1200 (Oxford, 1988), pp. 83-95; J. Blair, 'The Anglo-Saxon Church in Herefordshire: Four Themes', in A. Malpas et al, eds., The Early Church in Herefordshire (Leominster, 2001), pp. 3-13.

${ }^{30}$ Reg. Cantilupe, pp. 46-9, 79-80, 87-90, 95, 116-7; Reg. Swinfield, pp. 14-15, 39, 108-10, 131-2, 149-50; Rome, Vatican Archives, MS Vat. Lat. 4015, fo. 58r (we would like to thank Andrew Fleming of St Edmund Hall, Oxford, for this reference).
} 
of evidence during a subsequent dispute. There are stitch marks not only along the top, which indicate it had once been part of a roll, but also down the left-hand side, which suggests it had at another time been sewn into a book or quire of some kind; the foot has been cut.

The second document edited below is a fragment of a visitation conducted in 1286 dealing with faults and offences in Ashperton, Ledbury, Pixley and two unidentifiable parishes. ${ }^{31}$ This roll is not mentioned in the catalogue of the cathedral archives made during their evacuation to the National Library of Wales during the Second World War, but in March 1978 it was found by the then cathedral archivist Penelope Morgan in the county record office and shown to Christopher Whittick, who transcribed it. ${ }^{32}$ Repeated attempts by the present authors, the cathedral archivist, and the county archivist to find the roll have been unsuccessful and so our edition is based on the 1978 transcription. This visitation dealt with adultery, fornication, the mental instability of parish clergy, harbouring Welshmen, communicating with Jews, clerical concubines, sorcery (including an early reference to a witch's familiar: '[she] has an animal in the shape of a cat which sucks milk from the cows of her neighbours'), consanguinity, hindering the execution of a will, violence against a servant girl, sex with a servant girl, failure to provide lights for the church, a defective baptistry, a poorlyroofed chapel, a tumble-down rectory, and usury. It ends mid-way through an entry so cannot be complete.

\footnotetext{
${ }^{31}$ One of these may be Wellington, given the 'de Walinton' surnames.

32 B.G. Charles and H.D. Emanuel, A Calendar of the Earlier Hereford Cathedral Muniments (3 vols., Aberystwyth, 1955).
} 
A clear terminus post quem for this lost roll is provided by the reference to communicating with Jews in Hereford, clearly impossible after their expulsion or forced conversion in 1290; a terminus ante quem is not so clear, but Thomas le Breton, named in the document, was first recorded as a canon of Hereford in $1273 .{ }^{33}$ These are the limits of plausibility, but greater precision is possible. Three pieces of contextual information relating to faults reported during the visitation suggest a date in the spring or early summer of 1286 . The first entry for Ledbury refers to a priest who was 'freneticus et furiosus'. In Swinfield's register there is a commission for John Legat, chaplain, to act as a coadjutor for Reynold the vicar of Ledbury who suffers from 'quadam infirmitate phrenetica seu furoris.' The date is 29 July $1286 .{ }^{34}$ John Legat, who was a priest at St Katherine's Hospital in Ledbury, was himself reported in the visitation (because of suspicions about his relationship with a female servant). In addition to this the report of people 'communicating with Jews in Hereford' also finds corroboration in Swinfield's register, where two episcopal letters written in August and September 1286 express concerns about Christians attending a Jewish wedding. ${ }^{35}$ In December 1286 Swinfield was visiting Leominster Priory, but it is conceivable that this was a highly targeted inspection and that earlier in the year he had been engaged in visiting parishes. ${ }^{36}$ We know that in June 1286 he was in Colwall, close to Ledbury. ${ }^{37}$

A more speculative piece of evidence dating the fragment to 1286 involves the identification of Reynold Pauncefot, whose will was being contested by his kinsman

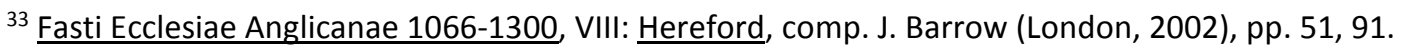

${ }^{34}$ Reg. Swinfield, p. 116.

${ }_{35}$ Reg. Swinfield, pp. 120-2.

${ }^{36}$ Reg. Swinfield, pp. 131-2, 149-50.

${ }^{37}$ Reg. Swinfield, pp. 112-3. 
Grimbald. Grimbald Pauncefot was a knight who held several Herefordshire and Gloucestershire manors from Roger Mortimer. He also pursued iron and timber interests in the Forest of Dean and elsewhere, served as keeper of the Forest in the 1280s, and received grants of the markets of Crickhowell and Much Cowarne in $1281 .{ }^{38}$ Reynold Pauncefot was frequently a witness to charters in and around Ledbury, where he held land abutting that of the bishop, in the mid-thirteenth century. ${ }^{39}$ Since the two men are mentioned in the visitation fragment in relation to Reynold's will, any record of his death would provide a secure terminus post quem for the document. There is, however, no inquisition post mortem for Reynold Pauncefot. However, we know that Grimbald believed himself entitled to a portion of Reynold's property, and there is a good deal of evidence for a dispute between Grimbald and one Reynold FitzPeter over feudal services deriving from Crickhowell, Wales. This dispute took place between 1282 and 1284 and Reynold FitzPeter, for whom we do have an inquisition post mortem, was dead before May $1286 .{ }^{40}$ Some doubt enters into the identification of Reynold Pauncefot with Reynold FitzPeter because the latter's correspondence with Grimbald makes no reference to a family relationship, but if it is correct then we may date the lost visitation fragment to May-August 1286.

Such a date would strongly suggest that the lost roll is a fragment of BOTER 3 and TALBOT 6: Swinfield's 'second circuit.' The retention of this particular fragment beyond

\footnotetext{
${ }^{38} \mathrm{Kew}$, TNA, C 47/11/4/7, C 143/21/2, SC 1/7/167, SC 1/45/25; HCA, 290; Cal. Ch. Rolls, 1257-1300, pp. 248, 258.

39 HCA, 290, 562, 578, 616, 1291, 1741, 2462.

${ }^{40}$ Calendar of Inquisitions Post Mortem, II: Edward I (London, 1906), pp. 346-6; J. Goronwy Edwards, ed., Calendar of Ancient Correspondence Concerning Wales (Cardiff, 1935), pp. 77-8, 116-7, 165; TNA, SC 1/30/172. Reynold Fitz Peter had also granted the market at Crickhowell to Hugh Turberville, before Hugh granted it to Grimbald.
} 
the 1350s, given that most of the documents extant at that date were subsequently discarded, may be explained by the number of offences involving high-status churchmen and laymen. William de Broy, whose wife was reported for adultery, was either the elderly lord of the manor of Aylinton, held in chief from the king, or his son, also called William, who would have been aged between 11 and 28 at the time of the visitation. ${ }^{41}$ The Pauncefot family were also important secular landholders: Grimbald's sister is commemorated by an impressive tomb in Ledbury parish church. ${ }^{42}$

Thomas le Breton, reported for keeping a concubine, was a canon of Hereford and a kinsman of Bishop John le Breton. But perhaps the most significant reports made to this visitation were those connected with Bishop le Breton's nephew, Robert le Breton, who had been cited for adultery. Robert had received land at Wellington within the episcopal manor of Ledbury from his uncle sometime between 1269 and 1275 . One of the witnesses to this grant had been Reynold Pauncefot and another had been John Solers, reported in 1286 for fornication. The lands had formerly belonged to Hugh of Wellington, clerk, who might be tentatively identified as 'Hugh, servant of the dean of Hereford', reported for adultery with Isabella le Pol. ${ }^{43}$ Doubts about the local goodstanding of witnesses to a bishop's patronage of his family, or concerns about the behaviour of two prominent landholding families, might have prompted a cautious administration at Hereford to preserve this fragment.

\footnotetext{
${ }^{41}$ Calendar of Inquisitions Post Mortem, III: Edward I (London, 1912), pp. 84-5; HCA, 1741.

42 J. Hillaby, Ledbury: a Medieval Borough (Almeley, 2005), pp. 57, 59.

${ }^{43}$ EEA: Hereford 1234-1275, no. 159.
} 
Further light is shed on the evidences in Talbot's and Boter's lists by the final document edited here: HCA 1076. This is a single parchment membrane measuring $176 \times 490 \mathrm{~mm}$ with a single round filing-hole at the head. The roll is an itinerary of Bishop Swinfield's visitation undertaken in 1293. Each entry specifies the date, the place visited, and whether procurations had been paid or were outstanding. It was clearly used as a means of accounting for the revenues of visitation. It shows signs of having been written in sections as the visiting party progressed from place to place. A typical entry reads 'Die jovis proximo sequenti visitavit idem dominus conventum de Chyrebury [Chirbury] et fuit in victualibus procuratus'. The same formula was used in TALBOT 3-7 and BOTER 1-5. In addition, the titles given to those documents by the canon-archivists are comparable with the incipit of HCA 1076: 'Visitation roll of the venerable father in Christ, Richard by the grace of God bishop of Hereford'.

HCA 1076 can be positively identified as BOTER 4. Both are dated 1293 and endorsed with the words 'Roll of the fourth visitation of his diocese by the lord [bishop]'. Comparing the original document with the fourteenth-century list entry reveals that Canon Boter made some subtle alterations as he noted down his findings. BOTER 4 reads:

‘Die sabbati proxima postquam cantatur Sitientes, videlicet anno Domini MCClxxxxii, visitavit dominus ecclesiam parochialem de Monemuta, die dominica in ramis palmarum visitavit idem dominus monachos loci et debetur procuratio pro utraque visitatione.' ${ }^{44}$

\footnotetext{
${ }^{44}$ Reg. Trillek, p. 222.
} 
But the entry for Monmouth in HCA 1076, seen by Boter, reads:

'Die sabbati visitavit dominus ecclesiam parochialem de Monemuta et debetur procuratio pro utraque visitatione. Die dominica in ramis palmarum visitavit idem dominus monachos loci.'

There are three discrepancies between the texts. To begin with, Boter gives the year, but this is easily explained as elucidation on his part: the 'videlicet' is his clarification of the date. The second discrepancy is the reference in Boter's text to the singing of the Sitientes, an antiphon from the liturgy often used to date documents to the Saturday before Passion Sunday, the fifth in Lent. The third discrepancy is the position of the phrase 'et debetur procuratio pro utraque visitatione', which Boter places after both the parish and priory entries, while the scribe of HCA 1076 has it between the parish and priory entries. In HCA 1076 a line has been drawn between the end of the parish entry and the end of the priory entry. This could have been made by the original scribe to indicate that the phrase 'for both visitations' applied to both the parish and the priory, but given the rearrangement apparently made by Boter it may be that this line is a correction in his own hand. In contrast to Talbot's chronological confusion, Boter emerges as a scrupulous editor, who not only saw HCA 1076 and used it in his list, but also clarified its meaning to make it more useful as part of Trillek's dossier against the claims of Monmouth.

On the basis of the lists, copies and original documents described here we can reconstruct the process, frequency and timing of the visitation regime under Bishops Cantilupe and Swinfield and reflect upon the close relationship between administrative 
routines, social processes, and written records. The figure below [INSERT FIGURE AS CLOSE TO HERE AS POSSIBLE] is a chronological list of all the visitations we can be sure they carried out, with one conjectural entry based on the ordinal numbers in the Talbot/Boter lists. When they conducted visitations there was a remarkable regularity of procedure and timing. This is particularly evident from the dates of the visitation of Monmouth in Boter's list: 22 March in 1276, 12 March in 1284, 9 March in 1287, and 30 March in 1293. The 1293 tour, recorded in HCA 1076, began on 22 January and involved visitations of parishes or religious houses on almost every day until 4 April; there was then a break until a shorter period of activity between 17 and 24 May, followed by three further visitations on 19 and 26 July, and 2 August. ${ }^{45}$ Swinfield began by following the river Lugg to Leominster, and then headed northwards in a sweep of the northern boundary of Shropshire archdeaconry. He went southwards following the Severn and back into the interior of the diocese along the river Teme to Ludlow and Bromfield, before crossing his tracks and zig-zagging his way down to Monmouth, heading northwards again to Ledbury, and then southwards down the Wye as far as its confluence with the Severn; finally he headed north-eastwards along the estuary before returning to Hereford. This route (see map) [INSERT MAP AS CLOSE TO HERE AS

POSSIBLE, WITH NUMBERED KEY ON FACING PAGE] marked out his territory in a large and slightly eccentric-looking figure-of-eight, allowing the bishop to spend a number of days in each deanery except that of Hereford itself, where the dean and chapter were

\footnotetext{
${ }^{45}$ The dating of a document in Reg. Swinfield, pp. 278-9, at the Kensington manor house of the abbot of Abingdon on 24 February 1293, when HCA 1076 reports he was at Burford, must cast some doubt on the question of whether the bishop was visiting in person or delegating his authority.
} 
the ordinary authority. A surviving roll of Bishop Swinfield's household expenses for 1289 and 1290 records an itinerary that roughly matches the northern part of this circuit, though going in the opposite direction and involving fewer stops. This may have been Swinfield's 'third circuit'. ${ }^{46}$ At each stopping-point the visitor would hear reports from the clergy and laity of several churches. For example, in 1284 (HCA 1050a) reports from eighteen churches were presented at what HCA 1076 reveals would have been no more than three visitation centres. We cannot tell from the latter document, however, exactly how the churches and chapels of an area were allocated to visitation centres. In gathering the clergy and representative laity from several parishes at a central point, Swinfield made life a little easier for himself, but still he used many more centres than those bishops in other English dioceses who stopped at only one church in each deanery. ${ }^{47}$ More frequent stops would have made the bishop more visible to his people and the visitation more accessible to those parishioners charged with making presentments about moral, social, administrative and material faults in their parishes. Swinfield's energy and assiduity were remarkable for the time, when it was not

${ }^{46} A$ Roll of the Household Expenses of Richard de Swinfield, Bishop of Hereford, during Part of the Years 1289 and 1290, ed. J. Webb (2 vols., Camden Society, ser. 1, 59, 62; London, 1854-55); a map based on this roll is given in J.R.H. Moorman, Church Life in England in the Thirteenth Century (Cambridge, 1946), p. 189.

${ }^{47}$ Bishops who divided deaneries into smaller groups of parishes included Corbridge (York, 1304), Melton (York, 1317-1340), Montacute (Worcester, 1334-1337), and Trefnant (Hereford, 1397): The Register of Thomas of Corbridge, Lord Archbishop of York, 1300-1304, ed. W. Brown (2 vols., Surtees Society, 138, 141; Durham, 1925-28), i. 144, 174-5, 209-10; Registrum Willelmi Melton: Pars Secunda, ed. D. Robinson (Canterbury and York Society, 71: Torquay, 1976-7), p. 6; R.M. Haines, The Administration of the Diocese of Worcester in the First Half of the Fourteenth Century (London, 1965), pp. 150, 163; HCA, 1779, passim. Bishops who grouped parishes by deanery included Giffard (Worcester, 1284-1300), Romeyn (York, 1286), Waltham (Salisbury, 1394), Repingdon (Lincoln, 1413): Episcopal Registers, Diocese of Worcester. Register of Bishop Godfrey Giffard, ed. J.W. Willis Bund (Oxford, 1902), pp. 232, 313, 530-1; The Register of John le Romeyn, Lord Archbishop of York 1286-1296, ed. W. Brown (2 vols., Surtees Society, 123, 128; Durham, 1913-1917), i. 189-90; The Register of John Waltham Bishop of Salisbury 1388-1395, ed. T.C.B. Timmins (Canterbury and York Society, 80; Woodbridge, 1994), pp. 129-68; Lincoln, Lincolnshire Archives, MS Vj/0, passim. 
uncommon for bishops to make their 'primary visitation' a statement of values for the episcopate, rather than a pattern to be repeated with any regularity. In touring the parishes and religious houses of Hereford diocese at least seven times, and making special visits to particularly problematic places, he was making a strong statement about the kind of bishop he intended to be, and the kind of reform he wished to promote in the diocese. Cantilupe, Hereford's saintly bishop, emerges as a less ardent reformer, but only in comparison to his zealous successor. His two systematic visitations in 1276 and 1280 did not stand alone. In 1277 he was arranging follow-up hearings for incorrigible cases discovered during the primary visitation, and in 1278 he visited Leominster Priory. Although the chronology of their visitations does not precisely meet the canonical expectation of episcopal visitation once every three years $(1276,1280$, $1284,1286$, c. $1290,1293,1297-8,1300,1303)$ it comes close enough, and shows that both bishops were striving to establish a regular pattern of interaction with the parishes of their diocese. ${ }^{48}$

This conduct of visitation was, furthermore, not merely recorded in a series of rolls and itineraries: we may say that it was made possible by those documents. The lay person's experience of episcopal visitation would have involved not only the presence of the lord bishop and the sight of their neighbours being corrected, but also the knowledge that the whole process was being recorded in writing. This would have empowered those who saw in the bishop an ally against local immorality or corruption, and perhaps terrified those against whom this alliance was turned. Visitation was a

\footnotetext{
${ }^{48}$ Triennial visitation was assumed as a norm by Gratian in his Decretum compiled in the mid-twelfth century: C. 10 q. 3 cc. 7, 9 in Corpus iuris canonici, ed. Richter and Friedberg, i. 624-6.
} 
social process in which writing played a crucial part. What is remarkable about the records discussed here is the proof they provide of a very active and regular system of visitation. Given the depth of the engagement with local society that these records demonstrate we need to remind ourselves that this was the first generation to experiment with the recorded visitation of the laity. As has been noted elsewhere, the practice of visitation owed much to the techniques and habits that lay behind manorial court rolls, the records of the common law courts, accounting, and other forms of written record. ${ }^{49}$ It formed part of a general leap in the ambition of all governing institutions at this time. The three documents edited below are fragmentary traces of this major change in Hereford diocese, and when placed in context they can be appreciated as evidence for a pioneering approach to diocesan administration and pastoral care.

\footnotetext{
${ }^{49}$ Forrest, 'Transformation'; id., 'Survival of Medieval Visitation Records'; id., 'Power and the People in Thirteenth-Century England', in J. Burton, P. Schofield and B. Weiler, eds., Thirteenth Century England, XV: Authority and Resistance in the Age of Magna Carta (Woodbridge, 2015).
} 
Figure: Visitations conducted by bishops Cantilupe and Swinfield

\begin{tabular}{|c|c|c|}
\hline Bishop and year & Parishes or religious houses? & Source \\
\hline $\begin{array}{l}\text { Cantilupe } 1276 \\
\text { Follow-up hearings in } 1277\end{array}$ & Parishes and religious houses & $\begin{array}{l}\text { BOTER } 1 \text { AND TALBOT 3; Reg. } \\
\text { Cantilupe, 46-9, 79-80, 87- } \\
9,95 \\
\text { Reg. Cantilupe, } 144-50\end{array}$ \\
\hline Cantilupe 1278 & Leominster Priory & Reg. Cantilupe, 116-7 \\
\hline Cantilupe 1280 & Parishes and religious houses & $\begin{array}{l}\text { BOTER } 1 \text { (second entry), } \\
\text { TALBOT 4, and Reg. } \\
\text { Cantilupe, 237-40; possibly } \\
\text { also TALBOT } 2 \text { and Reg. } \\
\text { Cantilupe, } 219,256-8\end{array}$ \\
\hline Swinfield 1283 & Leominster Priory & Reg. Swinfield, 14-15 \\
\hline Swinfield 1284 ( $1^{\text {st }}$ circuit $)$ & Parishes and religious houses & $\begin{array}{l}\text { BOTER } 2 \text { and HCA 1050a; } \\
\text { possibly also Talbot } 5 \text { but } \\
\text { dates confused. }\end{array}$ \\
\hline Swinfield 1286 ( $2^{\text {nd }}$ circuit) & Parishes and religious houses & $\begin{array}{l}\text { BOTER 3, TALBOT } 6 \text { and the } \\
\text { Lost Roll; Reg. Swinfield, } \\
\text { 131-2, 149-50 }\end{array}$ \\
\hline Swinfield $1287 \times 1293$ ( $3^{\text {rd }}$ circuit?) & Unclear & $\begin{array}{l}\text { Conjectural based on } \\
\text { circuit numbers }\end{array}$ \\
\hline Swinfield 1293 (4th circuit) & Parishes and religious houses & BOTER 4 and HCA 1076 \\
\hline Swinfield 1297 & St Katherine's Hospital, Ledbury & $\begin{array}{l}\text { Oxford, Bodleian Lib. MS } \\
\text { Rawlinson B. 329, fos. 2v- } \\
\text { 3r }\end{array}$ \\
\hline Swinfield 1298 ( $5^{\text {th }}$ circuit?) & Religious houses & TALBOT 7 \\
\hline Swinfield 1300 (6 th $^{\text {th }}$ circuit) & Parishes and religious houses & BOTER 5 \\
\hline Swinfield 1303 & Parishes & Reg. Swinfield, 388-9 \\
\hline
\end{tabular}


The route of Swinfield's visitation of 1283 (HCA 1076)

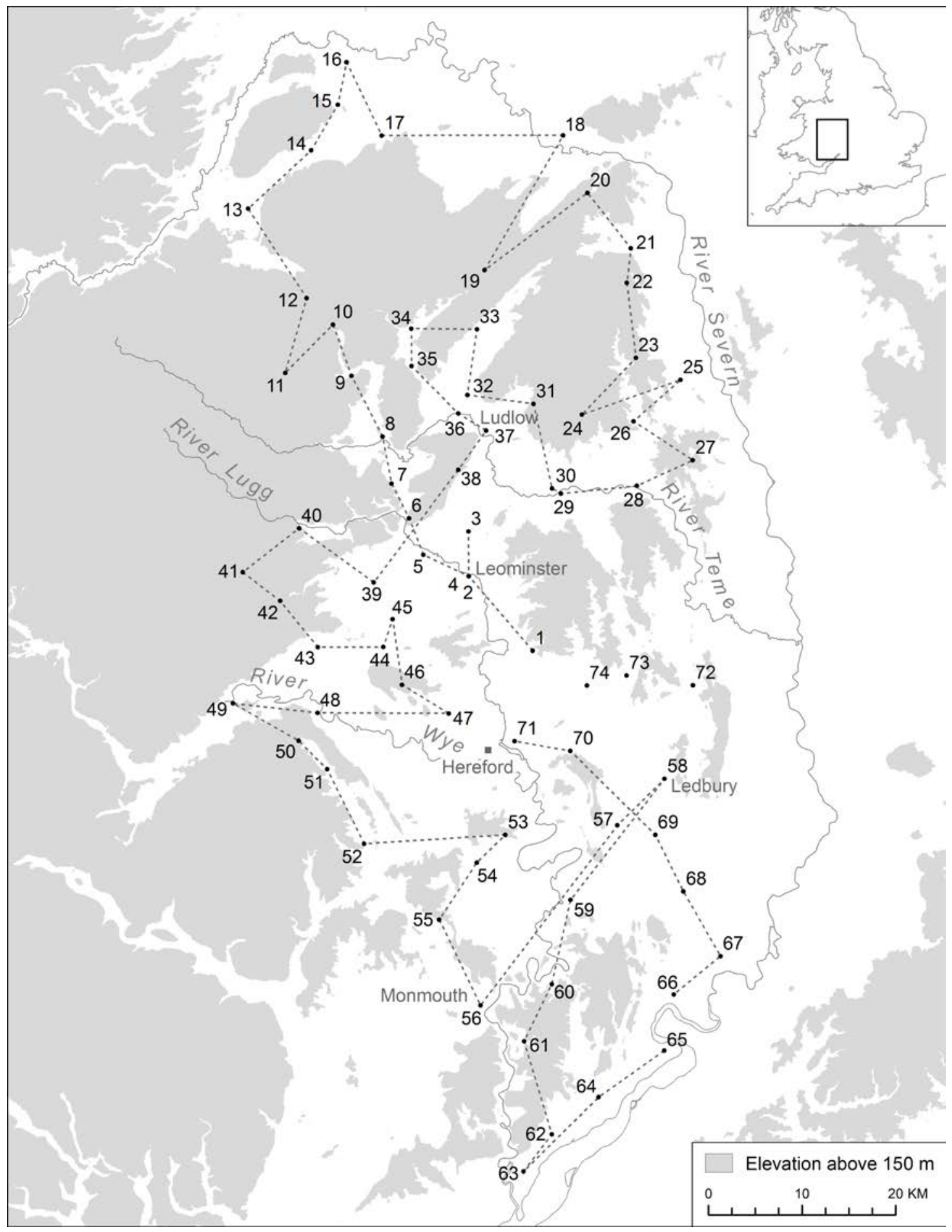




\section{$\underline{\text { Key to map }}$}

$1 \quad$ Bodenham

22 January

2 Leominster

23 January

3 Eye

24 January

$4 \quad$ Leominster Priory

25 January

$5 \quad$ Kingsland

26-7 January

6 Aymestrey

27 January

$7 \quad$ Wigmore and

Wigmore Priory

28-29 January

8 Leintwardine

30 January

$9 \quad$ Clunbury

31 January

10 Lydbury North

31 January

11 Clun

1 February

12 Bishops Castle

2 February

13 Chirbury and Chirbury

Priory

4-5 February

14 Worthen

6 February

15 Westbury

7 February

16 Alberbury

8 February

17 Pontesbury

9 February

18 Eyton on Severn or

Eaton Constantine

(Eton)

10 February

19 Rushbury

10-11 February

20 Wenlock

11 February

21 Morville (Momerfelle)

13 February

22 Chetton

14 February

23 Stottesdon

15 February

24 Doddington

16 February

\begin{tabular}{|c|c|c|c|}
\hline \multirow[t]{2}{*}{25} & Kinlet & 50 & Dorstone (Dorsinton) \\
\hline & 17 February & & 15 March \\
\hline \multirow[t]{2}{*}{26} & Cleobury Mortimer & 51 & Peterchurch \\
\hline & 18 February & & 16 March \\
\hline \multirow[t]{2}{*}{27} & Rock (Ake) & 52 & Abbey Dore \\
\hline & 19 February & & 17-18 March \\
\hline \multirow[t]{2}{*}{28} & Lindridge & 53 & Dewchurch with \\
\hline & 20 February & & Kilpeck and chapels \\
\hline \multirow[t]{2}{*}{29} & Tenbury & & 19 March \\
\hline & 21 February & 54 & Llanwarne \\
\hline \multirow[t]{2}{*}{30} & Burford & & 19 March \\
\hline & 22 February & 55 & Garway \\
\hline \multirow[t]{2}{*}{31} & Bitterley & & 20 March \\
\hline & 23 February & 56 & Monmouth and \\
\hline \multirow[t]{2}{*}{32} & Stanton Lacy & & Monmouth Priory \\
\hline & 24 February & & 21-22 March \\
\hline \multirow[t]{2}{*}{33} & Diddlebury & 57 & Much Marcle \\
\hline & 25 February & & 25 March \\
\hline \multirow[t]{2}{*}{34} & Wistanstow & 58 & Ledbury \\
\hline & 26 February & & 26 March \\
\hline \multirow[t]{2}{*}{35} & Stokesay & 59 & Ross \\
\hline & 27 February & & 29 March \\
\hline \multirow[t]{2}{*}{36} & Bromfield & 60 & English Bicknor \\
\hline & 28 February & & 30 March \\
\hline \multirow[t]{2}{*}{37} & Ludlow & 61 & Newland \\
\hline & $1 \mathrm{March}$ & & 31 March \\
\hline \multirow[t]{2}{*}{38} & Richards Castle & 62 & Woolaston \\
\hline & 2 March & & 1 April \\
\hline \multirow[t]{2}{*}{39} & Pembridge & 63 & Tidenham \\
\hline & 3 March & & 2 April \\
\hline \multirow[t]{3}{*}{40} & Presteigne & 64 & Lydney \\
\hline & (Prestemede) & & 3 April \\
\hline & 4 March & 65 & Awre \\
\hline \multirow[t]{2}{*}{41} & Old Radnor & & 4 April \\
\hline & $5 \mathrm{March}$ & 66 & Westbury-on-Severn \\
\hline \multirow[t]{2}{*}{42} & Kington & & 17 May \\
\hline & 6 March & 67 & Churcham \\
\hline \multirow[t]{2}{*}{43} & Almeley & & 18 May \\
\hline & 7 March & 68 & Newent \\
\hline \multirow[t]{2}{*}{44} & Weobley & & 19 May \\
\hline & $8 \mathrm{March}$ & 69 & Dymock \\
\hline \multirow[t]{2}{*}{45} & Dilwyn (Dylue) & & 20 May \\
\hline & 9 March & 70 & Stoke Edith \\
\hline 46 & Wormsley & & 23 May \\
\hline & 10 March & 71 & Lugwardine \\
\hline 47 & Burghill (Bornhull) & & 24 May \\
\hline & 11 March & 72 & Cradley (Credel) \\
\hline 48 & Bredwardine & & 19 July \\
\hline & $13 \mathrm{March}$ & 73 & Bishops Frome \\
\hline 49 & Clifford & & 26 July \\
\hline & 14 March & 74 & Much Cowarne \\
\hline & & & 2 August \\
\hline
\end{tabular}


Hereford Cathedral Archives, 1050a

Capella de Hop' under Dunemor

Visitata eodem die. Hec est capella dependens ab ecclesia de Leom'. Johannes capellanus ibidem. Willelmus Flemeng' fornicatur cum Christina la Hunter. Idem capellanus facit triturare pisas et fabas in ecclesia unde conqueruntur parochiani. Idem non deservit ecclesie secundum quod debuit. Item fecit cindi ij trabes in ecclesia in dampnum ecclesie et prejudicium parochie. Diffamatur de usuria. Item vadia que sibi ponuntur, nisi sint acquietate ad diem prefixum, sunt aliene, licet preter $\mathrm{xl}$ s. pro dimidia marce. Idem celebrat totaliter ad voluntatem domini R. de Hompton' militis. Stephanus Lange diffamatur de usuria. Ricardus molendinarius de Hop' adulterat cum Alicia relicta Willelmi Hour' de Hompton. Ricardus Sw.. fornicatur cum Agnete relicta Walteri Avonnest. Hugo de Mittleton adulteratur cum Maiota relicta Duluak. Willelmus de Hop' faber de Hulle acommodavit xvjs. ixd. et pro acommodatione recepit xxxiijs. Nicholas de Yeke male pertractat uxorem suam.

Pudlesdon

Ecclesia visitata eodem die. Dominus Thomas de Harwam rector ibidem. Rector de Humbr' percipit ibi decimas videlicet de Alicia quondam vidua de Brokhampton et Waltero clerico. Item parochiani non decimant oves cum eas vendiderunt. Dominus Thomas capellanus ibidem. Margeria la Cartar' fornicatur cum Philipo Cartar'. Dig.. Corson non pertractat uxorem suam maritali affectu. 
Dokkelowe

Capella in ecclesia Leom' visitata die Lune proxima post festum sancte Katerine anno predicto. Vicarius Leom' deservit ibidem per suos capellanos.

Stok'

Capella visitata eodem die; vicarius deservit ibidem ut supra. Simon Baldewyne fornicatur cum Matilda Andreu.

${ }^{50}$ Comparentibus $\mathrm{R}$ de Lacu et $\mathrm{R}$ rectore de Langaran coram $\mathrm{R}$ de Hoyton commissario speciali. Dicto Radulpho petente a prefato Ricardo v. marcas argenti ex causa mutui fide media. Dictus rector fatebatur intentionem dicti Radulphi promitens se soluturas ij. marcas dimidiam in festo purificationis et ij. marcas dimidiam in festo omnium sanctorum proximis sequentibus et est condempnatus.

Eye

Ecclesia visitata eodem die; Priore Leom' rector ibidem. Alexander vicarius ibidem residet. Rogerus Cromp' tenet publice Isabellam in domo Willelmi Bedelli. Idem Rogerus tenet in fornicatione Matildam braciatricem de Biriton. Item domina Johanna de Mereval tenet in concubinagium Galfridum Giffard et per multos annos tenuit post multas punitiones. Deficit unum velum quadragesime. Dominus de Eye subtrahit j lampadem quam invenire deberet. Rogerus Cromp' fornicatur et residet cum Tibota filia

\footnotetext{
${ }^{50}$ In margin 'condampnum'.
} 
Willelmi de Tangel'. Item dominus de Eye asportat cordas et scalas ab ecclesia ad edificium suum. Flaundre de Eye diffamatus de usuria.

Mittleton

Hec est capella de Eye. Dominus Ricardus capellanus ibidem et fuit visitata eodem die.

Orleton

Hec est capella de Eye; visitata eodem die.

Hop' Myle

Hec est capella dependens ab eadem ecclesia; visitata eodem die. Simon presbiter ibidem tenet injuste croftam que vocatur Cademonescroft' unde xij denarios debentur ad torticas illuminandas in elevatione corporis Christi, quos xij denarios detinuit per xij annos. Walterus de Campeden' tenet Margeriam filia Mabbe de Hope in fornicatione.

Lucton et Eyton

Hee sunt capelle dependentes ab ecclesia Leom'; visitate eodem die. Walterus de Wyneyate non pertractat uxorem suam modo [debito]. Johannes Bugein capellanus ibidem.

Kymbalton ${ }^{51}$

\footnotetext{
${ }^{51}$ Kimbolton
} 
Hec est capella ecclesie de Leom'. Dominus Johannes capellanus ibidem. Omnia bene.

Brymfeld $^{52}$

Hec est capella ecclesie predicte; visitata eodem die. Non est dedicata tamen corpora mortuorum ibidem sepiliuntur. Bricius ballivus de Brymfeld committit incestum cum ij sororibus quarum una vocatur Sibilla filia Willelmi de Brimfeld que peperit de eo iij proles. Alicia la Smythes vocatur altera soror. Robertus Bluettes eiusdem parochie comittit incestum cum Bouria filia domine de Mereval. Eleanora soror eiusdem Bourge committit incestum cum eodem. Adam Skiret de Orleton' est communis diffamator et pro tali reputatur a vulgo. Item deficit lucerna pro infirmis visitandis et velum quadragesimale.

Crofte

Hec ecclesia visitata eodem die. Dominus Nicholaus rector ibidem. [Omnia bene deleted by under-dots]. Isabella uxor Philipi Gody diffamatus de usuria.

Yarpol

Capella dependens ab ecclesia Leom'; visitata eodem die. Dominus J capellanus ibidem. Willelmus le Vinour non tractat uxorem suam modo debito. Johannes famulus Anore Moriz fornicatur cum Tibota Gerold.

52 Brimfield 
Adhuc Brymfeld

Ricardus Bernard committit incestum cum Constancia Hubert quam frater eiusdem duxit in uxorem. Henricus de Broka, Johannes Adames et Henricus de la Lee non comparuerunt in visitatione domini licet legitime citati. Ricardus de ${ }^{53}$ Drayton minatur apparitoribus domini ita quod non audent exequere officium suum. Alicia uxor Henrici Golafre adulteratur cum Thoma Rud capellano Leom'.

Prioratus de Lingebrok

Visitata die mercurie in vigilia sancti Andree apostoli anno domini supradicto proposito in capitulo per dominum .. Episcopum publice verbo dei; finitoque sermone semotis secularibus, idem dominus .. priorissam et quasdam maiores de conventu personaliter et alii sui clerici familiares ceteras de conventu super hiis que visitacionis officium requirebant ut decuit examinarunt. Et statim in capitulo ea que corrigenda fuerunt reperta correxit. Adiciens quod .. priorissa statum domus et bonorum quantum ad facultates et es alienum et cetera communitatem tangentia publice in capitulo bis face[ret] in anno ceteris de conventu ${ }^{54}$ notificaret.

Ecclesie de Ailmundestr' et de Shobbedon parochiales cum suis capellis de Leynthale et Lingaine

Visitate die Jovis in festo Sancti Andree anno predicto in ecclesia de Ailmondestre' per dominum .. episcopum Hereforden' primaria inquisitione repertum est quod alba et

\footnotetext{
${ }^{53} \mathrm{~A}$ mistake erased.

54 'visitaret' crossed out.
} 
amictus capelle de Lenthale sunt insufficientes; cancellum male coopertum; fenestre vitree sunt fracte. Rectores nichil boni faciunt in parochia. Egidius Turk de Lenthal fornicatur cum Juliana filia Ade de Wyles. Item deficit $\mathrm{j}$ cereus in capella de Lingaine in defectu rectorum. Item cancellum de Lyngaine male coopertum. Thurribbulum est insufficiens quorum reparatio spectat ad rectores. Dominus Ricardus de Schobbedon capellanus, ballivus domini Abbatis, diffamatus de usuria. Cancellum de Aylmundestr' est nimis obscurum. Dominus Robertus pistor subtrahit j cereum ponderis $\mathrm{j}$ li cerei coram altare sancte Marie. Johannes Arnald hoc idem. Dominus Hugo presbiter de Kyngesheived diffamatus de fornicatione cum Agnete de Lie, que est pregnans, licet prius purgaverit de eadem se duodecima manu. Johannes filius Petri molendinarii diffamatus de incesto commisso cum Margeria et Cecilia filiis Rogeri le Palmer de Wyggemore. Johannes vicarius <negat vj manu; ad proximam > tenet et tenuit per multos annos Emmam Patrich parochianam suam in adulterio.

Endorsed:

[c. 1350] Visitationes ecclesiarum Heref' diocesis facte per dominum Ricardum episcopum Hereforden' 


\section{Hereford County Record Office, lost visitation roll}

In parochia de Assperton'

......lisse $<\ldots$ purgavit se solempniter $>$ adulteratur cum uxore Gilberti de Homme <non

citatus, ideo citetur; purgavit se solempniter>

In parochia de Ledebur'

...... est debilis et impotens <in rotulo $>$ in tempore calido freneticus et furiosus et tunc dilapidat bona sua et rel[evet confessi]ones parochianorum ita quod aliquis eorum nec vult nec audet eidem confiteri nec alicui capellanorum, quia juvenes sunt, et ......stren set petunt quod possent confiteri dominis Willelmo Caperun, Rogero capellano Beate Marie et Symoni de Wych' ...

...... vicarius tenuit quandam Wallensem in domo sua per totum annum quam redemit de carcere domini episcopi per ...

...... de Wolputte similiter et quod communicat Judeis apud Hereford sicut Christianis. ...... presbiter parochialis <purgavit se> vocatur de filia Emme Biset Editha nomine cum qua in camera sua fuerat deprehensus.

......de de Lugyate < [purget se] ... manu coram decano; purgavit $>$ vocatur de sortilegio et dicitur quod habet animalem in forma cati quod suggit lac de vaccis vi[cinorum] ... ......eyn tenet puplice Aliciam de Walsnete consanguineam suam et eam ut dicitur impregnavit. < ... ideo et citatus si mulier citata; non citata, ideo citetur> ... le Botiler < ... citatus, iterum citetur $>$ et alii coexecutores Reginaldi Pauncefot non audent exequi voluntatem defuncti pro domino e[piscopo pro timore domini Grimbaldi] 
Pauncefot qui ab eis abstulit bona defuncti. <moneatur dominus Grimbaldus per decanum quod dicta bona restituat sub pena excommunicationis ut prius> ... Walle clericus vocatur de quadam que moratur apud Morton' cuius nomen ignoratur. ...nus de Hamme non exequitur voluntatem uxoris sue defuncte cuius est executor. <... reddidit compotum et officium remisit sibi misericordiam> ...rose vocatur de ancilla sua quia uxor sua paraliticatur. ${ }^{55}$

... Galfridus Forestar' < v manu purgavit se> adulteratur cum Gille Biset <purget v manu> nunc maritata.

... [W]alerand subdiaconus tenet quandam damam cuius nomen ignoratur < correctus ut supra patet>

...... [su]btrahit <... est prout apparet per rotulos consistorii > iij $\mathrm{d}$ annui redditus ad sustentationem j lampadis.

$\ldots v$ lampades deberent esse retro majus altare $<\ldots$ inquisitioni faciende per decanum, fiat inquisitio> quarum iij deberet capellanus Beate Marie invenire et diaconus ij. ... [v]ocatur de quadam muliere quam tenet in domo sua que pluries peperit eidem et vocatur Matilda Noker. < [purget] una manu; suspensus; excommunicatus et citatus; comparet et meruit absolvi et purgavit se> ... executrix frequenter accedit ad Philippum < purgavit se $>$ cocum presbiterum de la Hyde. $<$ [m]eruit absolvi et est in misericordia; compertum est illam non esse citata; purget vj manu; mulier suspensa et citata; excommunicata et citata>

\footnotetext{
${ }^{55}$ An interlined sentence is missing from this entry.
} 
Uxor Willelmi le Broy <differtur> vocatur super adulterium cum magistro Nigello Wallensi qui moratur London'.

...licus filius Willelmi Avenel <purgavit se prius coram Nicholao; suspensus et citatus; excommunicatus pro contumacia> adulteratur cum Margeria uxore Willelmi Fabri <suspensa etc; excommunicata; meruit absolvi et est in misericordia vj d; purget xij manu> ......ter tenet quandam <purgavit se > prope Asperton' vel Weston' cuius nomen ignoratur. $\ldots<$ prout supra $>$ [adu]|teratur cum Johanne Hayward <extra $>$ et Johanne le Driver <suspensus; excommunicatus; meruit absolvi et est in misericordia <xij d >; purgavit se> [In parochia] de Pykesleye Deficit baptisterium. $<$ non debet ubi aliquod esse $>^{56}$

[In parochia de] ...on

Walterus frater Thome le Rus de Maume vocatur de usura et ideo in curia canonicorum Hereford amerciatus fuit. <purget v manu; suspensus; excommunicatus; remaneat ut prius et citatus ut prius et citatus; comparet et meruit absolvi; misericordia correand' ..>

[In parochia de] ...

Johannes de Solers <suspensus; excommunicatus; excommunicatus publice; comparuit et meruit absolvi et purget ij manu; purgavit.> uxoratus vocatur de quadam muliere $<$ nomine filia ... de Pykeslee vocatur ... > cuius nomen ignoratur.

\footnotetext{
${ }^{56}$ Written in the same ink as the charge.
} 
Ri[cardus] ... <respicitur penitencia $>$ tenet puplice Katerinam filiam domine de Parco. <mulier citetur publico edicto in ecclesia, citeretur apud Hereford'; difertur> ...kon Blake adulteratur cum Anabilia de Parco <recenter excommunicata, citetur ad diem veneris post festum beati Petri ad vincula apud Heref'> que similiter adulteratur cum Ricard le Batur manens apud ...

Tibota la Bonde <non citata, iterum citata; extra $>$ pregnans est de Laurencio de Putteleye <non citatus, ideo citatus; extra> ...... Johannis ... <xij d $>$ vocatur de Matilda Wallensi

[De]ficiunt <citetur rector> in capella iij lampades per rectorem exhibende et duo cerei. Capella male est cooperta.

Hugyn serviens decani Hereford <purgavit se> adulteratur cum Isabella uxore ... hepol. <purget vj manu ... juris> Johannes Legat presbiter hospitalis de Ledebur' vocatur de ancilla Annye de Cruce. Dominus Robertus le Breton <suspensus; citatus; nunc reformatus et est in misericordia> adulteratur cum uxore Johannis Gorewy de Walinton. <non citata, ideo citetur; iterum citata> Thomas le Breton canonicus Hereford tenet puplice dominam Johannam de Colee $<$ non citata ideo citata; iterum citata; suspensa etc; excommunicata etc; difertur> Vicar de Ledebur' < difertur $>$ tenuit Anselisam de Walinton manentem apud Bereue. Ricardo de la Lyn ..... 


\section{Hereford Cathedral Archives 1076}

Rotulus visitationis venerabilis patris in Christo domini Ricardi dei gracia episcopi Heref' incepta die jovis in festo sancti Vincentii anno domini $\mathrm{M}^{\circ} \mathrm{CC}^{\circ}$ Nonagesimo secundo et ordinationis eiusdem patris decimo

Die jovis predicto [22 January] visitavit dominus ecclesiam de Bodenham et debetur procuratio

Die veneris sequenti [23 January] visitavit dominus ecclesiam parochialem Leom' et fuit ibidem per priorem in victualibus procuratus

Die sabbati sequenti [24 January] visitavit idem dominus ecclesiam parochialem de Eye et fuit per priorem apud Leom' in victualibus procuratus

Die dominica in conversione sancti Pauli [25 January] visitavit idem dominus priorem et conventus Leom' et fuit per priorem in victualibus procuratus

Die lune sequenti [26 January] dedicavit dominus ecclesiam parochialem de Kyngeslane et fuit per rectorem ibidem procuratus

Die martis sequenti [27 January] visitavit dominus eandem ecclesiam de Kyngeslane $<e t>$ debetur procuratio si dominus voluerit

Eodem die [27 January] incepit dominus visitare ecclesiam de Eylmondestre et ipsam visitationem complevit in crastino in ecclesia parochiali de Wygemore 
Die mercurii sequenti [28 January] visitavit idem dominus parochialem ecclesiam de Wygemore et fuit in abbatia per dominum abbatem in victualibus procuratus ${ }^{57}$

Die jovis sequenti [29 January] visitavit idem dominus conventum de Wygemore et fuit ibidem in victualibus procuratus

Die veneris sequenti [30 January] visitavit idem dominus ecclesiam de Leintwardin et debetur procuratio

Die sabbati sequenti [31 January] visitavit idem dominus ecclesiam de Clunbur' et restat procuratio si debetur

Eodem die [31 January] incepit dominus visitare ecclesiam de Lydebur' et die lune sequenti [2 February] eam complevit et debetur procuratio

Die dominica in $<$ vigilia $>^{58}$ purificationis [1 February] visitavit idem dominus ecclesiam de Clune et debetur procuratio $<$ Die purificationis [2 February] visitavit dominus ecclesiam Castri Episcopi> ${ }^{59}$ Die mercurii proxima sequenti [4 February] visitavit idem dominus parochialem ecclesiam de Chyrebur' et fuit ibidem in victualibus procuratus ${ }^{60}$ Die jovis proxima sequenti [5 February] visitavit idem dominus conventum de Chyrebur' et fuit in victualibus procuratus

Die veneris sequenti [6 February] visitavit idem dominus ecclesiam parochialem de Worthin et fuit ibidem in victualibus procuratus

\footnotetext{
57 Indicated by pointing finger.

58 Replacing festo, deleted.

59 The entry added at the end of previous entry.

60 Indicated by pointing finger.
} 
Die sabbati sequenti [7 February] visitavit idem dominus ecclesiam parochialem de All Westbury; et debetur procuratio

Die dominica in Quinquagesima [8 February] visitavit idem dominus ecclesiam parochialem de Albebur'; et debentur de procuratione pro visitatione illa iij marce tantum quia quarta tunc fuit soluta ${ }^{61}$

Die lune sequenti [9 February] visitavit idem dominus ecclesiam parochialem de Pauntesbur' et debet procuratio Die martis [10 February] incepit dominus visitare ecclesiam de Eton prioris et in crastino ipsam visitationem complevit Eodem die [10 February] martis incepit idem dominus visitare ecclesiam de Russebur' quam visitacionem in crastino [11 February] complevit

Die mercurii in capite jejunii [11 February] visitavit idem dominus parochialem ecclesiam de Wenlok et fuit ibidem in victualibus procuratus

Die jovis sequenti [12 February] fuit idem dominus omnibus sumptibus cum priore loci ad rogatum.

Die veneris sequenti [13 February] visitavit dominus ecclesiam de Momerfelle et fuit ibidem in victualibus procuratus

Die sabbati sequenti [14 February] visitavit idem dominus ecclesiam parochialem de Chetinton et debetur procuratio Die dominica prima quadragesime [15 February] visitavit idem dominus ecclesiam de Stottesdon et debetur procuratio

\footnotetext{
${ }^{61}$ Indicated by pointing finger; nota in margin.
} 
Die lune sequenti [16 February] visitavit idem dominus ecclesiam de Dodinton

Die martis [17 February] visitavit idem dominus ecclesiam parochialem de Kynlet et debetur procuratio

Die mercurii [18 February] visitavit idem dominus ecclesiam de Clebur' Mortemer et debetur procuratio

Die jovis [19 February] visitavit idem dominus ecclesiam del Ake et debetur procuratio Die veneris sequenti [20 February] visitavit dominus ecclesiam de $<$ Lyndregge $>^{62}$ et fuit ibidem in victualibus procuratus

Die sabbati sequenti [21 February] visitavit dominus ecclesiam de Temedebur' et debetur procuratio

Die dominica sequenti [22 February] visitavit idem dominus ecclesiam de Bureford et debetur procuratio

Die lune sequenti [23 February] visitavit dominus ecclesiam de Buterle et debetur procuratio

Die martis sequenti [24 February] visitavit dominus ecclesiam de Stauntoun et debetur procuratio

Die mercurii sequenti [25 February] visitavit dominus ecclesiam de Dudelbur' et debetur procuratio

Die jovis sequenti [26 February] visitavit dominus ecclesiam de Wilstanstowe et debetur procuratio, ut creditur, licet nichil nunc aut alias soluerit tempore domini

\footnotetext{
${ }^{62}$ Replacing Duterle [recte Buterle], deleted.
} 
Die veneris sequenti [27 February] visitavit idem dominus ecclesiam de Stoke Say et debetur procuratio

Die sabbati sequenti [28 February] visitavit idem dominus ecclesiam de Bromfeud et fuit ibidem in victualibus procuratus

Die dominica videlicet secunda ${ }^{63}$ quadragesime [1 March] dedicavit idem dominus summum altare in ecclesia de Lodelawe et fuit procuratus ibidem Die lune sequenti [2 March] visitavit idem dominus ecclesiam de Castro Ricardi et debetur procuratio

Die martis sequenti [3 March] visitavit idem dominus ecclesiam de Penebrugg' et fuit ibidem in victualibus procuratus

Die mercurii sequenti [4 March] visitavit idem dominus ecclesiam de Prestemede et debetur procuratio

Die jovis sequenti [5 March] visitavit idem dominus ecclesiam de Veteri Radenor et fuit ibidem in victualibus procuratus

Die veneris sequenti [6 March] visitavit idem dominus ecclesiam de Kynton Die sabbati [7 March] visitavit idem dominus ecclesiam de Almaly et fuit ibidem in victualibus procuratus

Die dominica in media quadragesima [8 March] visitavit idem dominus ecclesiam de Webbel' et debetur procuratio Die lune sequenti [9 March] dedicavit et visitavit idem dominus ecclesiam de Dylue et fuit apud Wormeleye ipso die in victualibus procuratus

\footnotetext{
${ }^{63}$ Recte tertia.
} 
Die martis sequenti [10 March] visitavit idem dominus priorem et canonicos de Wormel' et fuit ibidem in victualibus procuratus

Die mercurii sequenti [11 March] visitavit idem dominus ecclesiam de Bornhull et debetur procuratio ${ }^{64}$

Die veneris sequenti [13 March] visitavit idem dominus ecclesiam de Bredwarthyn Die sabbati sequenti scilicet quando cantatur sitientes [14 March] visitavit idem dominus ecclesiam de Clifford

Dominica in passione domini [15 March] visitavit idem dominus ecclesiam de Dorsinton et debetur procuratio

Die lune sequenti [16 March] visitavit idem dominus ecclesiam de Petreschirche Die martis sequenti [17-18 March] fuit dominus apud Doram sumptibus abbatis ad rogatum; et die mercurii similiter

Die jovis sequenti [19 March] visitavit idem dominus ecclesiam de Dowechurch cum Kylpek et capellis

Eodem die [19 March] visitavit dominus ecclesiam de Lanwaran et fuit procuratus in victualibus per priorem apud Moneketon ${ }^{65}$

Die veneris sequenti [20 March] visitavit idem dominus ecclesiam de Garewy et fuit in victualibus procuratus ibidem

Die sabbati [21 March] visitavit dominus ecclesiam parochialem de Monemuta et debetur procuratio pro utraque visitatione ${ }^{66}$

\footnotetext{
${ }^{64}$ The next four entries in a different ink but the same hand.

${ }^{65} \mathrm{~L} /$ written in the margin at which point a pin remains.

${ }^{66}$ Linked with a line to the end of the next entry, explaining the utraque visitatione.
} 
Die dominica ${ }^{67}$ in ramis palmarum [22 March] visitavit idem dominus monachos loci Die mercurii sequenti scilicet in festo Annunciationis dominice [25 March] visitavit dominus ecclesiam de Magna Markele et debetur procuratio.

Die jovis in cena domini [26 March] visitavit dominus ecclesiam de Ledebur' et debetur procuratio. <Hucusque xxxiiij procurationes in denariis et xxj in victualibus>.

Die dominica ante festum Pentecoste [29 March] visitavit idem dominus ecclesiam de Ros et fuit ibidem in victualibus procuratus

Die lune sequenti [30 March] visitavit idem dominus ecclesiam de Bykenor Anglicana; et debetur procuratio

Die martis sequenti [31 March] visitavit idem dominus ecclesiam de Nova Terra et debetur procuratio

Die mercurii sequenti [1 April] visitavit idem dominus ecclesiam de Wolaston; et fuit ibidem in victualibus procuratus

Die jovis sequenti [2 April] visitavit idem dominus ecclesiam de Tudenham; et debetur procuratio

Die veneris sequenti [3 April] visitavit idem dominus ecclesiam de Lydeneye; et fuit ibidem in victualibus procuratus

Die sabbati [4 April] visitavit idem dominus ecclesiam de Aura; et soluta est procuratio in denariis $^{68}$

Die pentecosta [17 May]visitavit idem dominus ecclesiam de Westbury; et fuit apud Munestreworthe in victualibus procuratus ${ }^{69}$

\footnotetext{
${ }^{67}$ Following sa deleted.

68 ' $q t^{\prime}$ ' in margin
} 
Die lune in septimana Pentecostis [18 May] visitavit idem dominus ecclesiam de Churcham.

Die martis sequenti [19 May] visitavit idem dominus ecclesiam de Newent; et fuit ibidem in victualibus procuratus

Die mercurii sequenti [20 May] visitavit idem dominus ecclesiam de Dymmuk; et debetur procuratio

Die sabbati proxima post festum sancte Trinitatis [23 May] visitavit idem dominus ecclesiam de Stok Edith; et fuit ibidem in victualibus procuratus.

Die dominica in octabo sancte Trinitatis [24 May] visitavit idem dominus ecclesiam de Lugwardin; et fuit ibidem in victualibus procuratus

Die dominica proxima ante festum beate Margarete [19 July] visitavit idem dominus ecclesiam de Credel' et debetur procuratio

Die dominica proxima sequenti [26 July] visitavit dominus ecclesiam de From' Episcopi et debetur procuratio

Die dominica sequenti videlicet in crastino sancti Petri ad vincula [2 August] visitavit dominus ecclesiam de Magna Koura

Endorsed:

[c1300] Rotulus <quarte> visitationis domini Ricardi diocesis sui que incipiebatur in festo conversionis sancti Pauli anno domini $\mathrm{M}^{\circ} \mathrm{CC}^{\circ}$ nonagesimo secundo $[c 1330]+$

69 ' $\mathrm{qt}^{\text {' in margin }}$ 
[c1670] Journall of visitation 1292

[c1750] 5 